\title{
Effects of enzymatic, sprouting and solvent methods on free and total gossypol reduction, oil content, flour yield and crude protein content
}

\author{
Varsha Satankar*, Mohan Singh ${ }^{1}$, V. Mageshwaran ${ }^{2}$ and Manoj Kumar ${ }^{3}$ \\ College of Agricultural Engineering, JNKVV, Jabalpur (M.P.) India \\ (Email: satankarvarsha@gmail.com)
}

\begin{abstract}
Use of cottonseed as protein source for food application and monogastric animals are restricted due to the presence of polyphenolic toxic content known as gossypol. Reduction of gossypol and improving crude protein content in cottonseed flour may increase its utility for feed and food industries. The present study aims to analyze the influence of three individual methods viz., sprouting method, enzymatic method and solvents method on free and total gossypol content, crude protein content, oil content and flour yield. Enzymatic treatments were performed using culture candida tropicalis, saccharomyces cerevisiae and combinations of both whereas for solvent treatments four different solvents namely acetone, ethanol, methanol and iso-propanol with their four different levels (70-100\%) were applied. Results of this study revealed that $70 \%$ aqueous acetone showed maximum free gossypol reduction (97\%), crude protein content $(65.6 \%)$, oil content $31.3 \%$ and $57 \%$ flour yield was observed. However, total gossypol reduction was only $51 \%$. Other side, enzymatic treatment based on candida tropicalis found more effective in terms of total gossypol reduction (73\%), however crude protein content was recorded only $39.4 \%$.
\end{abstract}

Key Words : Aqueous acetone, Gossypol, Crude protein, Solvent, Cottonseed, Culture

View Point Article : Satankar, Varsha, Singh, Mohan, Mageshwaran, V. and Kumar, Manoj (2021). Effects of enzymatic, sprouting and solvent methods on free and total gossypol reduction, oil content, flour yield and crude protein content. Internat. J. agric. Sci., 17 (2) : 371 376, DOI:10.15740/HAS/IJAS/17.2/371-376. Copyright@2021: Hind Agri-Horticultural Society.

Article History : Received : 25.02.2021; Revised : 27.02.2021; Accepted : 16.03.2021

\footnotetext{
* Author for correspondence : (Present Address) :

Ginning Training Centre, ICAR-CIRCOT, Nagpur (M.S.) India

${ }^{1}$ College of Agricultural Engineering, JNKVV, Jabalpur (M.P.) India

${ }^{2}$ ICAR- NBAIM, Kushmaur, Mau (U.P.) India

${ }^{3}$ ICAR-Central Institute for Research on Cotton Technology, Mumbai (M.S.) India
} 